\title{
Pemanfaatan Internet dalam Meningkatkan Kinerja Penyuluh Pertanian di Kabupaten Cianjur
}

\section{Utilization of Internet in Improving Performance of Agricultural Extension in Cianjur Regency}

\author{
Nanik Anggoro Purwatiningsih ${ }^{1}$, Anna Fatchiya ${ }^{2}$, Retno Sri Hartati Mulyandari ${ }^{3}$ \\ 'Balai Besar Pengkajian dan Pengembangan Teknologi Pertanian Bogor, Kementerian Pertanian \\ ${ }^{2}$ Departemen Sains Komunikasi dan Pengembangan Masyarakat, Fakultas Ekologi Manusia, \\ Institut Pertanian Bogor \\ ${ }^{3}$ Balai Pengelola Alih Teknologi Pertanian, Badan Penelitian dan Pengembangan Pertanian, \\ Kementerian Pertanian
}

\begin{abstract}
As science and technology have developed rapidly and the current globalization as well, farmers'needs are increasingly diverse today. As a result, extension workers are required to develop their abilities to face current conditions and challenges. However, they still have a lack of competence, which in turns causes a low performance as well. The reason for this is the lack of training for extension workers. Therefore, it is necessary to improve the performance of extension workers, and the use of the very rapidly growing media, the internet can be an answer. This study analyzed: 1) the level of internet utilization, 2) factors influencing internet utilization, and 3) the effect of internet utilization on extension worker performance. A field study was conducted in January-March 2017 in Cianjur Regency. The study sample involved 26 government extension workers and 74 contract-based extension workers. Descriptive statistics and inferential statistics (Multiple Linear Regression) were used for the analytical method. The results showed that the use of internet by extension workers was moderate, especially for preparing reports, designing extension methods, preparing "programma" and designing extension materials. The factors that affect the internet use are age, formal education, internet perception, duration, and diversity of the accessed internet media. Internet utilization affects the performance of extension-workers.
\end{abstract}

Keywords: agriculture, extension, internet, performance

\begin{abstract}
Abstrak
Pemanfaatan internet sangat penting dalam meningkatkan kinerja penyuluh, karena penyuluh dituntut untuk selalu mengembangkan kemampuannya sesuai kondisi dan tantangan saat ini.. Penelitian ini bertujuan menganalisis:1) tingkat pemanfaatan media internet oleh penyuluh, 2) faktor yang berpengaruh terhadap pemanfaatan internet oleh penyuluh, dan 3) pengaruh pemanfaatan internet terhadap kinerja penyuluh. Sampel penelitian adalah 26 penyuluh PNS dan 74 penyuluh THL. Metode analisis menggunakan statistik deskriptif dan statistik inferensial (Regresi Linier Berganda). Hasil penelitian menunjukkan bahwa pemanfaatan internet oleh penyuluh tergolong sedang, baik dalam hal penyusunan laporan, pembuatan rancangan metode penyuluhan, penyusunan programa, dan pembuatan materi penyuluhan. Faktor-faktor yang berpengaruh terhadap pemanfaatan internet adalah umur, pendidikan formal, persepsi terhadap internet, durasi, dan keragaman gawai/ gadget yang diakses. Pemanfaatan internet berpengaruh terhadap kinerja penyuluh pertanian.
\end{abstract}

Kata kunci: internet, kinerja, penyuluh, pertanian

\section{Pendahuluan}

Penyuluh merupakan ujung tombak pembangunan pertanian di Indonesia, yang dapat diartikan bahwa salah satu keberhasilan pertanian berada di tangan penyuluh karena penyuluh dapat berinteraksi langsung dengan petani, sehingga program-program pertanian dapat langsung diterapkan atau disampaikan kepada petani. Di samping menyampaikan program-program pembangunan, penyuluh juga mendorong petani untuk lebih maju, mempunyai wawasan yang luas dan berorientasi pada pasar. Hal ini berkaitan dengan peran penyuluh pertanian sebagai motivator. Penyuluh pertanian juga berperan sebagai inovator, fasilitator, konsultan, dan komunikator (Mardikanto, 2009). Mengingat pentingnya peran penyuluh kepada petani, penyuluh dituntut untuk mempunyai kompetensi dan kinerja yang tinggi. Namun demikian masih banyak penyuluh yang mempunyai kompetensi rendah (Marliati et al. 2008; Utami et al. 2008; Hidayat 2009; Bahua et al. 2013; Muliady 2009; dan Gatut 2008). Rendahnya

\footnotetext{
${ }^{1}$ Korespondensi penulis

E-mail: nanik.anggoro@gmail.com
} 
kompetensi penyuluh menghasilkan kinerja yang rendah pula, karena kompetensi berpengaruh terhadap kinerja penyuluh pertanian (Kusmiati et al, 2010; Hidayat 2009; Gilley dan Eggland 1989). Faktor yang mempengaruhi kinerja salah satunya adalah kurangnya program pendidikan dan pelatihan yang sesuai untuk peningkatan kapasitas bagi penyuluh (Turere 2013).

Kendala keterbatasan penyelenggaraan pelatihan bagi penyuluh ini, di antaranya dapat ditanggulangi dengan pemenuhan kebutuhan informasi yang berbasis internet, meskipun pemerintah melalui Permentan No 61 tahun 2008 telah mendorong penyuluh untuk meningkatkan kinerja revitalisasi penyuluhan pertanian. Revitalisasi penyuluhan pertanian yang sedang diupayakan berupa perbaikan kegiatan penyuluhan melalui pendidikan dan pelatihan.

Salah satu daerah yang telah melakukan revitalisasi penyuluhan di wilayah Jawa Barat adalah Kabupaten Cianjur. Di wilayah ini telah mengadakan pendidikan/pelatihan dan kesempatan pendidikan para penyuluh, namun karena keterbatasan anggaran, hanya sebagian penyuluh yang memiliki kesempatan pelatihan tersebut dan pelatihan yang diadakan masih sangat jarang.

Berkaitan dengan hal tersebut, penyuluh pertanian harus mencari alternatifuntuk meningkatkan wawasan dan pengetahuan guna meningkatkan kinerjanya. Selain permasalahan tersebut, pada saat ini hasil-hasil penelitian dan teknologi yang dikembangkan di bidang pertanian sudah sangat banyak dan selalu berkembang, namun hal ini belum dapat dimanfaatkan secara maksimal oleh penyuluh. Hal ini diakibatkan kurang diketahuinya informasi tersebut meskipun telah dipublikasi di berbagai media (Mulyandari 2011).

Mengingat terbatasnya kesempatan pelatihan/training yang diselenggarakan bagi para penyuluh, diperlukan upaya untuk meningkatkan kinerja penyuluh namun dengan biaya yang murah dan tidak dipengaruhi oleh jarak dan waktu, yaitu dengan pemanfaatan internet, misalnya cyber extension. Internet merupakan salah satu media yang dapat berperan sebagai alat bantu untuk mengoptimalkan dan mengembangkan kemampuan penyuluh pertanian. Melalui internet, informasi yang dibutuhkan untuk mengembangkan kemampuan tersedia dalam jumlah yang tidak terbatas dan dapat diakses secara cepat dan murah (Setiawan 2007). Ahuja (2011) juga mengemukakan bahwa ketersediaan informasi melalui internet membantu proses penyuluhan pertanian lebih cepat dan efektif. Banyaknya informasi yang mudah diakses secara cepat dan murah tersebut dapat dimanfaatkan oleh penyuluh untuk menambah pengetahuan, sehingga dapat meningkatkan kinerjanya.

Penelitian ini bertujuan untuk menganalisis: 1) tingkat pemanfaatan internet oleh penyuluh di Kabupaten Cianjur dalam mendukung tugas pokok dan fungsinya, 2) faktor-faktor yang berpengaruh terhadap tingkat pemanfaatan internet oleh penyuluh, 3) pengaruh tingkat pemanfaatan internet terhadap peningkatan kinerja penyuluh.

\section{Metode Penelitian}

Penelitian ini menggunakan pendekatan kuantitatif dan metode survey. Menurut Silalahi (2012), desain korelasional digunakan untuk melihat hubungan antara variabel-variabel dan menguji hipotesis yang telah dirumuskan, yaitu melihat gambaran peubah penelitian terkait tingkat kinerja penyuluh pertanian. Penelitian ini dilaksanakan di Kabupaten Cianjur, dengan kriteria Kabupaten Cianjur pernah mendapatkan pelatihan dan bantuan peralatan untuk mendukung akses internet dalam rangkaian program pemasyarakatan cyber extension dari pemerintah melalui Kementerian Pertanian. Dengan demikian penyuluh pertanian di Kabupaten Cianjur pernah menggunakan internet.

Pengumpulan data dilaksanakan dari bulan Januari hingga April 2017. Jumlah populasi sebanyak 216 orang penyuluh pertanian, terdiri atas 57 orang penyuluh PNS dan 159 orang penyuluh THL. Jumlah Sampel sebanyak 100 orang penyuluh yang terdiri atas 26 penyuluh PNS dan 74 penyuluh THL, berdasarkan konsep Fraenkel dan Wallen (1993). Data penelitian ini meliputi data primer dan data sekunder. Data yang terkumpul dianalisis secara diskriptif dengan melihat rataan dan persentase. Analisis data pada tingkat kinerja penyuluh pertanian diukur berdasarkan panduan yang tercantum pada Permentan No 91 tahun 2013. Tingkat pemanfaatan internet, karakteristik penyuluh, dukungan instansi, persepsi terhadap internet dan pola penggunaan internet diolah dengan ditabulasikan dan dijelaskan secara kualitatif. Analisis pengaruh setiap variabel $\mathrm{X}$ terhadap variabel $\mathrm{Y} 1$ dan $\mathrm{Y} 2$, pada data yang bersifat ordinal dianalisis menggunakan regresi linier berganda dengan menggunakan SPSS versi 20 dan excel 13. 


\section{Hasil dan Pembahasan}

\section{Karakteristik Penyuluh}

Karakteristik internal merupakan ciri-ciri khusus yang terdapat pada seseorang dan sangat menentukan kebutuhannya sehingga mampu mengarahkan kekuatan berdasarkan tuntutan pribadi. Karakteriktik penyuluh yang diidentifikasi meliputi umur, pendikan, kepemilikan media internet, dan kebutuhan informasi, sebagaimana disajikan pada Tabel 1.

Tabel 1. Persentase Responden berdasarkan Karakteristiknya

\begin{tabular}{|c|c|c|c|c|}
\hline \multirow{2}{*}{$\begin{array}{c}\text { Karakteristik } \\
\text { Penyuluh }\end{array}$} & \multirow{2}{*}{ kategori } & \multicolumn{2}{|c|}{$\begin{array}{c}\text { Status } \\
\text { Jabatan } \\
\end{array}$} & \multirow{2}{*}{ Total } \\
\hline & & $\begin{array}{l}\text { PNS } \\
(\%)\end{array}$ & $\begin{array}{l}\text { THL } \\
(\%)\end{array}$ & \\
\hline \multirow{3}{*}{$\begin{array}{l}\text { Umur (th) } \\
\text { Rataan }=40,5 \\
\text { Stdev }=10,60\end{array}$} & $\begin{array}{l}\text { Tua } \\
(48-60)\end{array}$ & 21 & 7 & 28 \\
\hline & $\begin{array}{l}\text { Dewasa } \\
(36-47)\end{array}$ & 6 & 28 & 34 \\
\hline & $\begin{array}{l}\text { Muda } \\
(23-35)\end{array}$ & 6 & 32 & 38 \\
\hline \multirow{5}{*}{$\begin{array}{l}\text { Pendidikan } \\
\text { Formal }\end{array}$} & S2 & 2 & 1 & 3 \\
\hline & S1 & 24 & 39 & 63 \\
\hline & D4 & 3 & 12 & 15 \\
\hline & D1 & 1 & 2 & 3 \\
\hline & SMA & 4 & 12 & 16 \\
\hline \multirow{4}{*}{$\begin{array}{l}\text { Kepemilikan } \\
\text { media internet } \\
\text { (unit) } \\
\text { Rataan }=3 \text {, } \\
\text { Stdev }=1,32\end{array}$} & 4-6 & 6 & 24 & 30 \\
\hline & $1-3$ & 26 & 40 & 66 \\
\hline & Tidak & 1 & 3 & 4 \\
\hline & Mempunyai & & & \\
\hline \multirow{5}{*}{$\begin{array}{l}\text { Kebutuhan } \\
\text { Informasi } \\
\text { (skor) } \\
\text { Rataan=25,02, } \\
\text { Stdev }=2,84\end{array}$} & $\begin{array}{l}\text { Tinggi } \\
(25,1-28)\end{array}$ & 8 & 35 & 43 \\
\hline & Sedang & & & \\
\hline & $(22,1-25)$ & 10 & 20 & 30 \\
\hline & Rendah & & & \\
\hline & $(19-$ & 15 & 12 & 21 \\
\hline
\end{tabular}

Keterangan: $\mathrm{N}=100$

Umur penyuluh di Kabupaten Cianjur ini sebagian besar (38\%) tergolong muda yaitu berkisar antara 23 tahun hingga 35 tahun. Sementara penyuluh yang tergolong tua sebanyak $28 \%$ dengan kisaran usia lebih dari 48 tahun. Penyuluh yang masih berusia muda memungkinkan untuk dapat terlibat aktif dalam memberikan penyuluhan kepada petani karena masih tergolong usia yang produktif. Penyuluh yang produktif juga berpotensi dapat mengikuti perkembangan-perkembangan teknologi yang semakin canggih, seperti penggunaan internet sebagai media mendapatkan informasi yang lebih banyak mengenai permasalahan-permasalahan yang berkaitan dengan kegiatan penyuluhannya. Oleh karena itu, akan berdampak pada kinerjanya yang lebih baik. Hal ini sejalan dengan hasil penelitian yang dilakukan oleh Bahua et al. (2013) bahwa umur penyuluh sangat berpengaruh pada kinerja.

Penyuluh yang berumur produktif memiliki fisik yang lebih kuat dan lebih kreatif dibanding dengan penyuluh yang sudah tidak produktif, namun yang menjadi kelemahan bagi penyuluh terutama yang masih muda cenderung memiliki sifat cepat bosan pada pekerjaan yang dijalaninya, seperti hasil penelitian yang dilakukan Wuriani et al. (2014) bahwa pekerja dengan umur yang masih muda memiliki kelemahan cepat bosan, tanggungjawab yang rendah, sering tidak masuk dan memiliki keinginan yang tinggi untuk pindah-pindah kerja.

Pendidikan merupakan salah satu faktor yang dapat mempengaruhi pola pikir seseorang. Semakin tinggi tingkat pendidikan yang dimiliki oleh seseorang, maka wawasannya akan semakin tinggi pula sehingga akan meningkatkan keterlibatan orang tersebut dalam melaksanakan tugasnya (Lastinawati, 2011). Tingkat pendidikan juga sangat berperan bagi penyuluh dalam menjalankan tanggung jawabnya pada petani.

Pendidikan formal penyuluh di Kabupaten Cianjur mayoritas telah menempuh hingga Strata 1 (S-1) yaitu mencapai 63\%, sementara yang berpendidikan Sekolah Menengah Atas (SMA) hanya $16 \%$. Hal ini menggambarkan bahwa penyuluh di Kabupaten Cianjur rata-rata telah berpendidikan tinggi, sehingga memiliki kemampuan yang memadai untuk melaksanakan tugasnya sebagai penyuluh. Pentingnya pendidikan bagi seorang penyuluh adalah sebagai landasan dalam membentuk, mempersiapkan, membina serta mengembangkan kemampuan sumber daya manusia seperti yang dikemukakan oleh Ningrum (2013). Selain faktor umur dan pendidikan, kepemilikan media internet juga akan mempengaruhi kinerja penyuluh.

Kepemilikan media internet, berdasarkan hasil penelitian pada Tabel 1 dapat diketahui bahwa media internet yang dimiliki oleh penyuluh di Kabupaten Cianjur sebagian besar (66\%) 1-3 unit. Hal ini menggambarkan bahwa media untuk mengakses 
internet yang dimiliki penyuluh sangat memadai. Kondisi yang demikian memudahkan penyuluh untuk mendapatkan informasi-informasi yang berkaitan dengan kegiatan penyuluhannya. Adapun media internet yang banyak dimiliki oleh penyuluh di wilayah ini di antaranya adalah $\mathrm{Hp}$ berinternet dan laptop, iPad/Tab, ataupun Smart TV.

Teknologi informasi dan komunikasi yang dimanfaatkan dengan baik dapat berpotensi meningkatkan kapasitas seseorang. Adanya peningkatan kapasitas tersebut akan berdampak pada kinerja yang lebih baik. Namun untuk hal itu semua harus didukung dengan media internet yang memadai. Media yang dapat digunakan untuk mengakses internet di antaranya berupa Handphone (Hp), Laptop/netbook, iPad maupun Tablet (Tab), Komputer, dan komputer/desktop yang terhubung dengan jaringan internet. HP berinternet baik yang berupa Tab maupun iPad merupakan media yang cukup praktis untuk transfer atau berbagi informasi. Penelitian Lestari (2010) juga mengatakan bahwa akses internet sudah dapat diatasi dengan adanya media Hanphone atau ponsel.

Selain umur, pendidikan formal, dan kepemilikan media internet, karakteristik penyuluh lainnya adalah kebutuhan informasi. Kebutuhan informasi yang dimaksud dalam penelitian ini merupakan keharusan atau tuntutan bagi seorang penyuluh untuk memperkaya (memperoleh) berbagai jenis informasi yang dibutuhkan mengenai pertanian. Informasi yang dibutuhkan oleh penyuluh dalam penelitian ini adalah informasi mengenai: 1) Teknologi produksi yang meliputi benih unggul, penanaman, pemupukan, pengairan, pengendalian OPT, dan panen, 2) Informasi mengenai teknologi pasca panen dan pengemasan produk, 3) Pemasaran hasil produksi yang meliputi harga pasar dan peluang pasar, 4) Iklim dan lingkungan pertanian, 5) Permodalan, dan 6) Informasi mengenai kelembagaan. Informasi yang diperoleh tersebut dapat digunakan sebagai bahan penyusunan materi penyuluhan, dan menyusun laporan.

Berdasarkan hasil penelitian, diketahui bahwa kebutuhan informasi bagi penyuluh sebagian besar (43\%) dalam kategori tinggi. Kebutuhan akan informasi ini merupakan hal penting yang mendorong para penyuluh menggunakan internet. Hal ini sejalan dengan yang dikemukakan oleh Pittman (2009), bahwa internet saat ini menjadi cara utama untuk mengumpulkan informasi. Pada dasarnya, informasi yang dibutuhkan oleh para penyuluh secara umum mulai dari informasi teknis produksi hingga penanganan pasca panen dan pemasaran hasil produksi. Namun demikian, informasi yang sangat dibutuhkan oleh penyuluh berdasarkan hasil penelitian ini adalah informasi mengenai pemasaran hasil produksi.

Penelitian Suryantini(2004)juga menemukan bahwa informasi yang diperoleh penyuluh melalui internet digunakan untuk menyusun materi penyuluhan, menyusun materi pengajaran pada kursus petani, membuat pedoman teknis, untuk menyusun rencana kerja penyuluh pertanian, sebagai acuan untuk melakukan pengkajian/pengujian teknologi anjuran, untuk evaluasi dan pelaporan kegiatan penyuluhan, menyusun programa penyuluhan, membuat makalah untuk seminar, lokakarya, temu teknis, temu tugas dan untuk membuat karya tulis yang akan diterbitkan.

\section{Dukungan Instansi}

Kelancaran dalam penggunaan internet oleh penyuluh perlu adanya berbagai dukungan. Salah satu dukungan tersebut dapat berasal dari instansi di mana penyuluh tersebut bekerja. Dukungan instansi merupakan faktor-faktor dari luar pribadi penyuluh yang diduga berpengaruh dengan tingkat pemanfaatan internet. Dukungan instansi yang dianalisis dalam penelitian ini meliputi pelatihan dalam pemanfaatan TIK dan dukungan finansial dengan hasil sebagaimana disajikan pada Tabel 2.

Tabel 2. Persentase Responden berdasarkan Dukungan Instansi

\begin{tabular}{llc}
\hline Dukungan Instansi & \multicolumn{1}{c}{ Kategori } & $\begin{array}{c}\text { Persentase } \\
(\mathbf{\%})\end{array}$ \\
\hline Pelatihan TIK (skor) & Selalu $(7,67-11)$ & 36 \\
Rataan $=4,25$ & Sering $(4,34-7,66)$ & 5 \\
Stdev $=3,63$ & Jarang $(1-4,33)$ & 59 \\
Dukungan Finansial & Tinggi $(5,1-7)$ & 11 \\
(skor) & Sedang $(3,1-5)$ & 20 \\
Rataan $=3,64$ & Rendah $(1-3)$ & 69 \\
Stdev $=1,33$ & & \\
\hline
\end{tabular}

Keterangan: $\mathrm{N}=100$

Pelatihan TIK merupakan keterlibatan penyuluh dalam kegiatan pelatihan pemanfaatan TIK, khususnya dalam akses internet untuk peningkatan kapasitas penyuluh. Tujuan pelatihan TIK adalah meningkatkan pemahaman penyuluh dalam 
pemanfaatan internet agar lebih terampil dalam menggunakannya untuk mendukung peningkatan kinerjanya. Berdasarkan hasil penelitian yang disajikan pada Tabel 2, diketahui bahwa sebagian besar (59\%) responden mengatakan masih jarang terlibat dalam pelatihan TIK. Hal ini di karenakan pelatihan yang diadakan untuk penyuluh masih jarang. Hanya terdapat $36 \%$ responden yang selalu mengikuti pelatihan TIK. Pelatihan yang pernah diikuti tersebut di antaranya adalah pelatihan mengenai cyber extension, sms center, membuat blog, dan pemanfaatan media sosial melalui WhatsApp (WA), Facebook (FB), dan teknologi informasi untuk pertanian. Selain dukungan berupa pelatihan TIK, instansi juga perlu memberikan dukungan finansial bagi penyuluh dalam mengakses internet.

Berbagai media yang dimanfaatkan untuk mengakses internet merupakan salah satu bentuk kemajuan teknologi. Suatu teknologi yang digunakan akan membutuhkan biaya untuk operasionalnya, sehingga akan berdampak terhadap pengeluran individu yang menggunakan teknologi tersebut. Hal ini sejalan dengan yang dikemukakan oleh Mardikanto (1993), bahwa teknologi yang tersedia membawa konsekuensi ekonomi yang akan ditimbulkan (tambahan biaya investasi, pemelihaan, dan biaya operasional). Selain itu, Mardikanto (2003) juga menuliskan bahwa di dalam manajemen, pembiayaan merupakan unsur penting, bahkan seringkali dianggap terpenting, karena sesuai perkembangan peradaban hampir tidak ada sesuatu yang harus dibeli tanpa uang.

Dukungan finansial sebagian besar responden untuk akses internet masuk dalam kategori rendah. Penyuluh jarang mendapatkan biaya khusus untuk akses internet dari instansi, sehingga untuk memenuhi kebutuhan biaya akses internet penyuluh harus menyediakan sendiri, padahal faktor penunjang seperti pembiayaan dari instansi ini sangat penting karena akan berpengaruh pada tingkat pemanfaatan internet. Hal ini sejalan dengan hasil penelitian Anggoroseto (2012), bahwa pembiayaan mempunyai besar pengaruh yang dominan dan signifikan terhadap pemanfaatan cyber extension. Rendahnya dukungan finansial ini akan menyebabkan terkendalanya penyuluh dalam mengakses internet, karena untuk mengaktifkan jaringan internet penyuluh harus mengalokasikan dana setelah kebutuhan pokok lainnya terpenuhi. Instansi tempat penyuluh bekerja yang menyediakan fasilitas internet hanya ada beberapa instansi saja, tidak semua instansi menyediakan fasilitas internet. Fasilitas akses internet yang disediakan oleh beberapa instansi tersebut di antaranya berupa WiFi.

\section{Persepsi tentang Internet}

Persepsi adalah pendapat maupun penilaian responden tentang internet yang meliputi manfaat internet, kualitas internet, serta kemudahan mengakses internet tersebut. Persepsi penyuluh tentang pemanfaatan internet secara keselurahan termasuk positif. Persepsi penyuluh tentang internet secara rinci disajikan pada Tabel 3.

Tabel 3. Persentase Responden berdasarkan Persepsi tentang Internet

\begin{tabular}{|c|c|c|}
\hline Persepsi & Kategori & $\begin{array}{c}\text { Persentase } \\
\quad(\%)\end{array}$ \\
\hline \multirow{3}{*}{$\begin{array}{l}\text { Manfaat internet (skor) } \\
\text { Rataan }=17,35 \\
\text { Stdev }=2,39\end{array}$} & $\begin{array}{l}\text { Sangat Bermanfaat } \\
(15,67-20)\end{array}$ & 74 \\
\hline & $\begin{array}{l}\text { Bermanfaat } \\
(11,34-15,66)\end{array}$ & 24 \\
\hline & $\begin{array}{l}\text { Tidak bermanfaat } \\
(7-11,33)\end{array}$ & 2 \\
\hline \multirow{3}{*}{$\begin{array}{l}\text { Kualitas informasi } \\
\text { (skor) } \\
\text { Rataan }=21,60 \\
\text { Stdev }=4,45\end{array}$} & Tinggi $(25,1-30)$ & 16 \\
\hline & Sedang $(20,1-25)$ & 44 \\
\hline & Rendah (15-20) & 40 \\
\hline \multirow{3}{*}{$\begin{array}{l}\text { Kemudahan diakses } \\
\text { (skor) } \\
\text { Rataan }=15,76 \\
\text { Stdev }=2,43\end{array}$} & Tinggi $(14,67-20)$ & 74 \\
\hline & Sedang $(9,34-14,66)$ & 25 \\
\hline & Rendah $(4-9,33)$ & 1 \\
\hline Persepsi total (skor) & Positif $(38,35-52)$ & 72 \\
\hline Rataan $=41,82$, Stdev & Netral $(24,68-38,34)$ & 27 \\
\hline$=5,66$ & Negatif $(11-24,67)$ & 1 \\
\hline
\end{tabular}

Keterangan: $\mathrm{N}=100$

Penilaian responden tentang manfaat yang diperoleh dari menggunakan internet dalam penelitian ini sebagian besar (74\%) termasuk dalam kategori sangat bermanfaat. Hal ini menggambarkan bahwa dengan adanya internet dapat memberikan kemudahan bagi penyuluh untuk mendapatkan informasi yang diperlukan sebagai pendukung kegiatan penyuluhannya. Manfaat dari informasiinformasi yang mudah didapat tersebut akan memperluas wawasan diri penyuluh.

Manfaat lain yang dapat dirasakan penyuluh dengan mengakses informasi melalui internet adalah 
dapat segera mengetahui informasi-informasi yang terbaru seputar perkembangan pertanian. Melalui jaringan internet, penyuluh juga dapat melakukan diskusi bersama penyuluh lain maupun bersama petani binaannya melalui email, maupun media sosial lainnya, misalnya: BBM, WhatsApps, ataupun Facebook.

Persepsi tentang kualitas informasi merupakan penilaian responden mengenai mutu informasi yang diperoleh melalui internet. Menurut Misrawi (2010) yang dikutip oleh anggoroseto (2012) bahwa kualitas informasi dari website dapat dilihat dari: tema, akurasi terkait sumbernya, tujuan, kompetensi pembuat informasi, dan aktualisasi. Berdasarkan hasil penelitian persepsi responden terhadap kualitas informasi yang diperoleh dari internet sebagian besar (44\%) adalah dalam kategori sedang.

Bagi penyuluh, informasi-informasi yang diperoleh dari internet dapat dipercaya. Hal ini dapat diamati dari sumber informasinya yang sudah jelas. Informasi seputar pertanian yang diakses oleh penyuluh berasal dari lembaga yang terpercaya, dan informasi yang berasal dari kasus-kasus petani yang telah berhasil di daerah lain. Oleh karena itu menurut penyuluh kualitas informasi yang diakses tidak diragukan lagi akan kebenarannya. Berdasarkan hasil penelitian yang dilakukan Elian (2015) menemukan bahwa kualitas dari informasi dapat meningkatkan kapasitas penyuluh sebagai penyuluh pertanian. Hasil penelitian Anggoroseto (2012), juga menemukan bahwa aktualisasi dan sumber yang dapat dipercaya berpengaruh langsung terhadap kinerja penyuluh dalam pemanfaatan cyber extension.

Persepsi tentang kemudahan akses ini merupakan penilaian responden terhadap kemudahan dalam mengakses informasi melalui internet. Berdasarkan hasil penelitian yang telah disajikan pada Tabel 3 diketahui bahwa persepsi sebagian besar (72\%) responden tentang kemudahan mengakses internet termasuk kategori tinggi. Penyuluh menganggap bahwa informasi yang tersedia di internet tidak terbatas, sehingga memudahkan penyuluh mencari berbagai informasi yang dibutuhkan. Kemudahan mengakses informasi melalui internet tersebut didukung dengan adanya smartphone yang saat ini dapat mengakses internet dengan biaya yang terjangkau. Berdasarkan hal tersebut dapat membuat penyuluh bisa mengakses informasi kapan dan di mana saja sesuai dengan kebutuhan, selagi handphone tersebut menjangkau jaringan.

\section{Pola Penggunaan Internet}

Pola penggunaan internet dalam penelitian ini meliputi durasi, keragaman gawai (gadget) untuk akses internet, dan pengeluran biaya untuk mengakses internet. Durasi mengakses internet merupakan lamanya waktu penyuluh dalam menggunakan internet, sementara itu keragaman media internet yang diakses adalah jenis-jenis layanan yang diakses melalui internet, dan pengeluaran biaya merupakan persepsi penyuluh tentang banyaknya biaya yang dikeluarkan untuk menggunakan internet. Hasil penelitian mengenai pola penggunaan internet secara rinci disajikan pada Tabel 4.

\section{Tabel 4. Persentase Responden berdasarkan Pola Penggunaan Internet}

\begin{tabular}{lll}
\hline \multicolumn{1}{c}{ Peubah } & \multicolumn{1}{c}{ Kategori } & $\begin{array}{c}\text { Persentase } \\
(\%)\end{array}$ \\
\hline Durasi (skor) & Tinggi $(10,35-15)$ & 27 \\
Rataan $=8,59$ & Sedang $(5,68-10,34)$ & 62 \\
Stdev $=3,15$ & Rendah $(1-5,67)$ & 11 \\
Keragaman gawai & Tinggi $(>3)$ & 23 \\
(gadget) internet & Sedang $(2-3)$ & 45 \\
yang diakses (jenis) & Rendah $(<2)$ & 32 \\
Pengeluaran untuk & Tinggi $(13,67-18)$ & 51 \\
mengakses internet & Sedang $(4,34-13,66)$ & 46 \\
(skor) & & \\
Rataan $=7,53$, Stdev Rendah $(1-4,33)$ & 3 \\
$=1,67$ & & \\
\hline
\end{tabular}

Keterangan: $\mathrm{N}=100$

Durasi penggunaan internet atau lamanya seseorang menggunakan internet dipengaruhi oleh beberapa faktor, di antaranya adalah motif orang tersebut menggunakan internet, jaringan hubungan internet (sinyal), dan biaya yang harus dikeluarkan untuk akses internet. Hasil penelitian menunjukkan bahwa sebagian besar (62\%) responden, durasi dalam menggunakan internet termasuk sedang. Lamanya durasi penyuluh dalam menggunakan internet disebabkan oleh penyuluh yang tidak hanya mencari informasi yang berkaitan dengan pertanian saja, melainkan juga mengakses informasi-informasi lain di luar sektor pertanian. Penyuluh terkadang setelah mengakses informasi utama, juga mengakses akun media sosial yang dimilikinya, seperti Facebook, instagram serta situs berita-berita sosial seperti olah 
raga sepak bola dan hiburan lainnya. Sebagian besar responden menggunakan waktu mencari informasi melalui internet hanya selama 0 hingga 2 jam dalam satu minggu. Keragaman media internet yang diakses digolongkan menjadi tiga kategori yaitu: $<2$ media internet, 2-3 media internet, dan $>3$ media internet.

Berdasarkan hasil penelitian yang disajikan pada Tabel 4, diketahui bahwa sebagian besar (45\%) responden mengakses 2-3 media internet. Sedangkan jenis layanan yang diakses melalui internet oleh penyuluh di antaranya meliputi website, media sosial, email, dan video call. Dari beberapa jenis layanan tersebut, yang paling dominan diakses oleh penyuluh adalah media sosial. Penyuluh lebih banyak mengakses media sosial karena lebih ditujukan untuk berkomunikasi dengan komunitas maupun kerabat lainnya di samping juga untuk mendapatkan hiburan. Hal ini sejalan dengan penelitian yang dilakukan oleh Veronice (2013) bahwa informasi yang sering diakses oleh penyuluh salah satunya adalah media sosial.

Pengeluaran untuk mengakses internet dikelompokkan menjadi tiga kategori, yaitu: tinggi, sedang, dan rendah. Hasil penelitian yang disajikan pada Tabel 4 menunjukkan bahwa sebagian besar (51\%) responden, pengeluaran untuk mengakses internetnya termasuk dalam kategori tinggi. Sebagian besar responden menyatakan bahwa untuk mengakses internet tergantung kondisi keuangan yang dimiliki. Adapun besar biaya internet yang dikeluarkan oleh sebagian besar responden berkisar antara 50.000,- hingga 100.000,-per bulan. Oleh karena itu bagi sebagian besar responden berpendapat bahwa internet tidak dapat diakses dengan biaya yang murah.

\section{Pemanfaatan Internet}

Pemanfaatan internet dalam melaksanakan tugas penyuluh meliputi pemanfaatan untuk bahan penyusunan laporan, pembuatan materi peyuluhan, penyusunan programa penyuluhan, dan desain metode penyuluhan. Tingkat pemanfaatan internet oleh penyuluh secara keseluruhan termasuk dalam kategori sedang. Hasil penelitian terhadap masing-masing komponen pemanfaatan internet dideskripsikan pada Tabel 5:

Tingkat pemanfaatan informasi yang diperoleh melalui akses internet dalam penyusunan laporan oleh penyuluh dinilai berdasarkan kategori rendah, sedang, dan tinggi. Hasil penelitian menunjukkan bahwa pemanfaatan internet oleh penyuluh dalam menyusun laporan sebagian besar $(60 \%)$ termasuk kategori sedang.

Kondisi tersebut menggambarkan bahwa sebagian besar penyuluh tersebut hanya kadangkadang menyusun laporan berdasarkan referensi dari internet. Penyuluh juga terkadang mengunjungi website pertanian saat akan membuat laporan penyuluhan. Hanya ada $27 \%$ penyuluh yang menyusun laporan selalu menggunakan informasi berasal dari internet. Penyuluh tersebut juga memanfaatkan berita

Tabel 5. Persentasi Responden berdasarkan Tingkat Pemanfaatan Internet

\begin{tabular}{llc}
\hline \multicolumn{1}{c}{ Peubah } & \multicolumn{1}{c}{ Kategori } & Persentase (\%) \\
\hline Menyusun laporan (skor) & Tinggi $(13,67-18)$ & 27 \\
Rataan $=11,68$ & Sedang $(9,34-13,66)$ & 60 \\
Stdev $=2,50$ & Rendah $(5-9,33)$ & 13 \\
Pembuatan materi (skor) & Tinggi $(14,35-19)$ & 20 \\
Rataan $=11,93$ & Sedang $(9,68-14,34)$ & 58 \\
Stdev $=2,99$ & Rendah $(5-9,67)$ & 22 \\
Penyusunan program (skor) & Tinggi $(13,1-17)$ & 30 \\
Rataan $=11,56$ & Sedang $(9,1-13)$ & 52 \\
Stdev $=2,92$ & Rendah $(5-9)$ & 18 \\
Desain metode penyuluhan (skor) & Tinggi $(11,35-15)$ & 15 \\
Rataan $=8,83$ & Sedang $(7,68-11,34)$ & 55 \\
Stdev $=2,35$ & Rendah $(4-7,67)$ & 30 \\
Total pemanfaatan internet (skor) & Tinggi $(49,1-64)$ & 3 \\
Rataan $=44$ & Sedang $(34,1-49)$ & 83 \\
Stdev $=8,93$ & Rendah $(19-34)$ & 14 \\
\hline
\end{tabular}

Keterangan: $\mathrm{N}=100$ 
seputar pertanian dalam penyusunan laporannya dan berdiskusi sesama penyuluh melalui internet (misalnya email, BBM, dan Whatapps).

Materi penyuluhan merupakan pesan yang ingin dikomunikasikan oleh seorang penyuluh kepada masyarakat sasaran. Pesan-pesan yang akan dikomunikasikan pada masyarakat sasaran dapat berbentuk informatif maupun persuatif, namun pada dasarnya informasi yang akan dikomunikasikan pada kegiatan penyuluhan haruslah bersifat inovatif. Hal ini agar dapat mendorong terjadinya perubahanperubahan pada masyarakat sasaran ke arah pembaharuan dalam aspek kehidupan. Pembaharuan tersebut demi selalu terwujudnya perbaikan-perbaikan mutu hidup masyarakat sasaran. Adanya tuntutan bagi seorang penyuluh untuk menyampaikan materi yang inovatif tersebut, mengharuskan penyuluh selalu mengupdate informasi yang akan disampaikan dan yang dibutuhkan oleh masyarakat sasarannya. Hal ini dapat dengan mudah dilakukan melalui pemanfaatan internet.

Berdasarkan hasil penelitian yang disajikan pada Tabel 5, pemanfaatan internet oleh penyuluh untuk membuat materi penyuluhan sebagian besar (58\%) termasuk dalam kategori sedang. Penyuluh dalam menyusun modul penyuluhan menggunakan referensi dari jurnal-jurnal terkait yang diakses memalui internet. Selain itu, penyuluh juga sering membuat leaflet dan poster penyuluhan berdasarkan referensi yang diperoleh melalui internet. Pada sisi lain, agar materi yang akan disampaikan pada masyarakat sasaran mudah dipahami, terkadang penyuluh menyiapkan materi tersebut dalam bentuk video. Pembuatan video tersebut dilakukan oleh penyuluh dengan bantuan tutorial yang tersedia di internet.

Programa merupakan rencana kegiatan penyuluhan yang memadukan aspirasi masyarakat sasaran dengan potensi wilayah serta program pembangunan pertanian yang menggambarkan keadaan sekarang, tujuan yang ingin dicapai, masalahmasalah yang sedang dirasakan, dan alternatif solusinya, serta cara mencapai tujuan, disusun secara partisipatif, sistematis, dan harus tertulis pada setiap tahunnya. Penyusunan programa penyuluhan harus melalui tahapan perumusan, penulisan, dan pengesahan. Unsur-unsur tersebut berkaitan satu dengan lainnya dan ada hubungan sebab akibat. Penyusunan programa penyuluhan dilakukan oleh penyuluh bersama-sama pelaku utama, pelaku usaha dan organisasi petani yang ada secara partisipatif.
Oleh karena itu sebagai seorang penyuluh mempunyai tanggung jawab dalam penyusunan programa tersebut. Agar programa yang akan dibuat dapat tersusun dengan baik, maka seorang orang penyuluh harus memperkaya informasi untuk menunjang penyusunan programa tersebut.

Berdasarkan hasil penelitian pada Tabel 5, diketahui bahwa sebagian besar (52\%) responden dalam penyusunan programa termasuk kategori sedang. Hal ini menggambarkan bahwa penyuluh terkadang menggunakan internet dalam penyusunan programa. Referensi yang akan digunakan dalam penyusunan programa, penyuluh menggunakan jurnal-jurnal terkait yang diperoleh dari internet. Penyuluh juga mengunjungi website pertanian untuk mencari referensi-referensi penyusunan programa. Selain itu penyuluh juga saling berdiskusi dengan penyuluh lainnya mengenai penyusunan programa tersebut. Diskusi yang dilakukan kadang-kadang melalui media sosial seperti BBM, Whatapps, facebook, dan email.

Selain penyusunan programa, salah satu hal yang harus menjadi perhatian penyuluh sebelum mengkomunikasikanpesankepadamasyarakatsasaran adalah metode penyuluhan yang akan digunakan. Penyuluh dituntut untuk mampu memahami dan memilih metode penyuluhan yang paling baik untuk diterapkan dalam proses penyuluhannya. Hal ini dilakukan dengan maksud agar tujuan penyuluhan yang telah ditetapkan dapat tercapai dengan baik. Adapun hasil penelitian pada Tabel 5, menunjukkan bahwa pemanfaatan internet untuk desain metode penyuluhan, sebagian besar (55\%) tergolong sedang. Hal ini menggambarkan bahwa penyuluh terkadang menggunakan internet untuk mendesain metode penyuluhan yang akan diterapkan. Penyuluh kadang-kadang juga menggunakan internet untuk mencari referensi metode-metode yang lebih efektif untuk digunakan dalam penyampaian pesan dalam penyuluhan.

\section{Tingkat Kinerja Penyuluh Pertanian}

Kinerja merupakan suatu yang dicapai, prestasi yang diperlihatkan, ataupun kemampuan kerja. Kinerja menurut Uno dan Lamatenggo (2012) adalah pengekspresian dari potensi yang dimiliki oleh seseorang dalam suatu bidang tertentu. Berkaitan dengan kinerja penyuluh pertanian, kinerja dalam hal ini merupakan eksistensi penyuluh dalam memahami keterkaitan tugas dan kebutuhan dasar program 
penyuluhan pertanian berkualitas dan relevan dengan kebutuhan petani. Sebaran penyuluh berdasarkan kinerjanya disajikan pada Tabel 6 .

Tabel 6. Persentase Responden berdasarkan Nilai Prestasi Kerja

\begin{tabular}{lc}
\hline Nilai Prestasi Kerja & Persentase (\%) \\
\hline Baik & 10 \\
Cukup & 61 \\
Kurang & 22 \\
Buruk & 7 \\
\hline Total & 100 \\
\hline
\end{tabular}

Keterangan: $\mathrm{N}=100$

Kinerja penyuluh pertanian di Kabupaten Cianjur berada pada kategori cukup, yaitu sebanyak $61 \%$. Sementara hanya ada $7 \%$ responden yang memperoleh nilai prestasi kerja yang termasuk dalam kategori buruk. Semua penyuluh di Kabupaten Cianjur dalam menjalankan tugasnya telah membuat data potensi wilayah yang terdiri dari peta wilayah kerja, peta potensi wilayah kerja dan permasalahan agribisnis yang ditemukan, monografi wilayah kerja, dan RKPD (Rencana Kegiatan Penyuluhan Desa). Selain itu semua penyuluh juga telah melakukan pengawalan dan pendampingan penyusunan RDKK, juga penyusunan program penyuluhan dan rencana kerja tahunan penyuluh pertanian (RKTPP).

Penilaian yang rendah bagi penyuluh pertanian di Kabupaten Cianjur di antaranya dalam hal menumbuhkan dan mengembangkan kelembagaan di masyarakat. baik pada Badan Usaha Milik Petani (BUMP) yang berbentuk Perseroan Terbatas (PT) dan sudah berbadan hukum, BUMP yang berbentuk PT \& belum berbadan hukum, BUMP yang berbentuk Koperasi Tani sudah berbadan hukum, maupun BUMPyang berbentuk Koperasi Tani belum berbadan hukum.

Selain itu juga masih rendah dalam pembuatan laporan tri wulan dan laporan setiap semester. Penyuluh yang mengerjakan BUMP yang berbentuk PT dan sudah berbadan hukum hanya ada $6 \%$, sementara BUMP yang belum berbadan hukum ada $10 \%$ penyuluh. Penyuluh yang mengembangkan dan menumbuhkan BUMP berbentuk Koperasi Tani sudah berbadan hukum hanya ada $17 \%$, dan yang belum berbadan hukum ada sebanyak $20 \%$ penyuluh.

\section{Faktor-faktor yang Mempengaruhi Tingkat Pemanfaatan Internet}

Pengaruh karakteristik penyuluh, dukungan instansi, persepsi terhadap internet dan pola penggunaan internet dengan tingkat pemanfaatan internet dianalisis dengan menggunakan analisis regresi linier berganda. Persamaan regresi yang diperoleh dari peubah bebas terhadap tingkat pemanfaatan internet adalah:

$\mathrm{Y}=30.272-0.329 \mathrm{X}_{1.1}+2.837 \mathrm{X}_{1.2}+6.659 \mathrm{X}_{1.3}-0.181$ $\mathrm{X}_{1.4}-0.425 \mathrm{X}_{1.5}-0.359 \mathrm{X}_{2}+0.468 \mathrm{X}_{3}+1.484 \mathrm{X}_{4.1}+$ $3.834 \mathrm{X}_{4.2}+3.371 \mathrm{X}_{4.3}$

Hasil analisis dari setiap variabel tersebut terdapat pada Tabel 7.

Tabel 7. Pengaruh Karakteristik Penyuluh, Dukungan Instansi, Persepsi, dan Pola Penggunaan terhadap Tingkat Pemanfaatan Internet

\begin{tabular}{|c|c|c|c|}
\hline Sub Peubah & $\begin{array}{c}\text { Koefisien } \\
\text { regresi }\end{array}$ & $\mathbf{t}$ & Sig \\
\hline$\overline{\text { Constant }}$ & 30,272 & 3,433 & 0,001 \\
\hline \multicolumn{4}{|l|}{ Karakteristik } \\
\hline \multicolumn{4}{|l|}{ Penyuluh $\left(\mathrm{X}_{1}\right)$} \\
\hline $\operatorname{Umur}\left(\mathrm{X}_{11}\right)$ & $-0,329$ & $-3,616$ & $0,001 * *$ \\
\hline Tingkat pendidikan & 6,659 & 3,105 & $0,003 * *$ \\
\hline Kepemilikan media & $-0,181$ & $-0,270$ & 0,787 \\
\hline Kebutuhan ${ }^{1}$ informasi & $-0,425$ & $-1,539$ & 0,127 \\
\hline Dutkungan instansi & $-0,359$ & $-1,856$ & 0,067 \\
\hline $\begin{array}{l}\text { Persepsi terhadap } \\
\text { internet }\left(X_{3}\right) \\
\text { Pola Penggunaan }\end{array}$ & 0,468 & 2,814 & $0,006^{* *}$ \\
\hline Internet $\left(\mathrm{X}_{4}\right)$ & & & \\
\hline $\begin{array}{l}\text { Durasi }\left(\mathrm{X}_{4.1}\right) \\
\text { Keragaman gawai/ }\end{array}$ & 1,484 & 4,003 & $0,000 * *$ \\
\hline $\begin{array}{l}\text { Keragaman gawai/ } \\
\text { gadget yang diakses } \\
\left(\mathrm{X}_{4,2}\right)\end{array}$ & 3,834 & 4,823 & $0,000 * *$ \\
\hline $\begin{array}{l}\text { Pengeluaran akses } \\
\text { internet }\left(\mathrm{X}_{4.3}\right)\end{array}$ & 3,371 & 1,599 & $0, \mathrm{u} 113$ \\
\hline
\end{tabular}

Keterangan: ${ }^{* *}$ ) sangat nyata pada $\mathbf{a}=0,01$

Karakteristik penyuluh yang berpengaruh nyata terhadap tingkat pemanfaatan internet hanya variabel tingkat pendidikan formal. Hal tersebut menggambarkan bahwa semakin tinggi tingkat pendidikan seorang penyuluh maka semakin tinggi tingkat pemanfaatan internetnya. Hal ini disebabkan karena seseorang yang berpendidikan tinggi, 
penggunaan media internet sudah tidak asing lagi, sehingga untuk keperluan penyuluhan langsung dapat menggunakan atau mengakses informasi melalui internet tersebut. Hasil penelitian ini sejalan dengan hasil penelitian yang dilakukan oleh Mundorf dan Laird (2008) bahwa pendidikan berpengaruh terhadap penggunaan internet. Responden dengan pendidikan formal yang lebih tinggi, akan membuat diri individu tersebut lebih terbuka dan lebih siap dengan pengetahuan baru.

Sementara itu variabel kepemilikan media internet, dan kebutuhan informasi negatif tidak berpengaruh terhadap pemanfaatan internet. Hal ini menggambarkan bahwa semakin meningkatnya variabel-variabel tersebut tidak dapat meningkatkan pemanfaatan internet oleh penyuluh. Beda halnya dengan variabel umur, variabel umur berpengaruh negatif terhadap pemanfaatan internet. Hal ini menjelaskan bahwa semakin meningkatnya umur seseorang maka akan menurunkan pemanfaatan internet oleh individu tersebut. Adanya penuaan umur seseorang maka produktivitas individu tersebut akan semakin menurun, keterampilan dalam hal kecepatan, kecekatan, kekuatan, dan koordinasinya juga akan menurun seiring berjalannya waktu (Robbins, 1998). Hasil penelitian ini sejalan dengan hasil penelitian yang dilakukan oleh Anggoroseto (2012), yang menyatakan bahwa umur berpengaruh dalam pemanfaatan cyber extension.

Kepemilikan media internet dan kebutuhan informasi juga negatif tidak berpengaruh pada tingkat pemanfaatan internet, yang berarti peningkatan jumlah media internet yang dimiliki tidak membuat peningkatan pada pemanfaatannya. Padahal hasil penelitian menunjukkan bahwa kepemilikan media internet pada penyuluh di lokasi penelitian sebagian besar lebih dari tiga unit, yang artinya media internet yang dimiliki sudah sangat mendukung untuk akses internet. Namun pada kenyataannya belum mampu meningkatkan pemanfaatan internet tersebut. Hal ini disebabkan meskipun sudah banyak memiliki media internet, namun media tersebut jarang digunakan untuk mengakses internet, media tersebut hanya sering digunakan untuk berkomunikasi melalui sms dan telepon saja. Hasil penelitian ini bertolak belakang dengan hasil penelitian yang dilakukan Anggoroseto (2012), bahwa kepemilikan sarana teknologi informasi berpengaruh terhadap pemanfaatan cyber extension.

Dukungan instansi juga tidak berpengaruh terhadap pemanfaatan internet. Hasil ini menggambarkan bahwa semakin meningkatnya dukungan instansi tidak dapat meningkatkan pemanfaatan internet oleh penyuluh. Hal ini disebabkan meskipun tidak adanya dukungan dari instansi, bagi penyuluh masih dapat mengakses informasidi internetdenganmenggunakan smartphone yang digunakan secara individu. Beda halnya dengan persepsi penyuluh terhadap pemanfaatan internet.

Persepsipenyuluhberpengaruhnyataterhadap pemanfaatan internet. Hal ini menggambarkan bahwa semakin baik persepsi penyuluh terhadap internet, maka pemanfaatan internet akan semakin meningkat. Persepsi tersebut baik pada manfaat internet, kualitas informasi dari internet, maupun persepsi pada kemudahan mengakses internet. Hasil penelitian menunjukkan bahwa persepsi sebagian besar responden terhadap internet adalah tinggi. Penyuluh mempercayai bahwa dengan menggunakan internet akan banyak manfaat yang diperoleh, penyuluh juga berkeyakinan bahwa kualitas informasi yang berasal dari internet dapat dipercaya, dan penyuluh juga merasakan mengakses informasi melalui internet lebih mudah dan lebih cepat dari pada menggunakan sumber informasi yang lainnya. Hal ini sejalan dengan yang dikemukakan oleh Leeuwis (2004) bahwa kecepatan/aktualitas informasi pada media internet lebih cepat dibandingkan dengan media massa lainnya, karena berita dan aktualitas sering ada sebelum disiarkan oleh radio atau televisi maupun surat kabar.

Pada faktor pola penggunaan internet, variabel yang tidak berpengaruh pada tingkat pemanfaatan internet hanya variabel pengeluaran untuk akses internet, sementara variabel yang berpengaruh adalah durasi dan keragaman gawai/gadget yang diakses oleh penyuluh. Durasi dalam penggunaan internet berpengaruh positif terhadap pemanfaatan internet, hal ini bermakna bahwa semakin lama durasi maka akan semakin meningkatkan pemanfaatan internet. Kondisi ini diakibatkan karena semakin lama mengakses internet maka informasi yang diperoleh cenderung akan semakin banyak, sehingga hal tersebut akan semakin menambah wawasan individu penyuluh untuk dikomunikasikan kepada petani sasaran.

Hasil penelitian ini bertolak belakang dengan hasil penelitian yang dilakukan oleh Elian (2015), bahwa seberapa sering dan seberapa lamanya penyuluh menggunakan internet tidak berpengaruh terhadap pemanfaatan informasi tersebut oleh penyuluh. Keragaman media internet juga berpengaruh 
terhadap tingkat pemanfaatan internet. Hal ini menjelaskan bahwa semakin tinggi keragaman media internet yang diakses, maka semakin meningkatkan pemanfaatan internet oleh penyuluh. Pengeluaran untuk akses internet tidak berpengaruh terhadap tingkat pemanfaatan internet. Hal ini menggambarkan bahwa semakin tinggi pengeluaran untuk membiayai akses internet, maka tidak dapat meningkatkan pemanfaatan internet. Kondisi demikian berkaitan dengan ketersediaan biaya yang dimiliki penyuluh untuk mengakses internet.

\section{Pengaruh Tingkat Pemanfaatan Internet Terhadap Kinerja Penyuluh}

Kinerja penyuluh merupakan kemampuan atau hasil kerja penyuluh berdasarkan pada status kerja, kondisi kerja, dan kebijakan organisasi dalam mengimplementasikan program penyuluhan. Hal ini meliputi persiapan kegiatan penyuluhan, pelaksanaan, dan evaluasi kegiatan penyuluhan. Kinerja penyuluh dalam kegiatan-kegiatan tersebut diduga dipengaruhi oleh tingkat pemanfaatan internet. Pemanfaatan internet merupakan salah satu kinerja penyuluh dalam memanfaatkan perkembangan TIK. Pemanfaatan media internet oleh penyuluh pertanian berkaitan dengan motif dan kebutuhan penyuluh terhadap informasi di media internet.

Tabel 8. Pengaruh Tingkat Pemanfaatan Internet terhadap Kinerja Penyuluh

\begin{tabular}{lccc}
\hline Sub Peubah & $\begin{array}{c}\text { Koefisien } \\
\text { regresi }\end{array}$ & T & Sig \\
\hline $\begin{array}{l}\text { Constant } \\
\text { Tingkat } \\
\text { pemanfaatan } \\
\text { internet }\end{array}$ & 46.354 & 204.775 & $0.000^{* *}$ \\
\hline
\end{tabular}

Keterangan: $\left.{ }^{*}\right)$ sangat nyata pada $\mathbf{0}=0,01$

Berdasarkan hasil analisis pada Tabel 8, menunjukkan bahwa tingkat pemanfaatan internet berpengaruh terhadap kinerja penyuluh. Hal ini ditunjukkan oleh nilai signifikan sebesar 0,000, angka tersebut jauh lebih kecil dari nilai probabilitas sebesar 0,05 . Kondisi tersebut menggambarkan bahwa semakin meningkatnya pemanfaatan internet maka akan meningkatkan kinerja penyuluh.

Semakin sering penyuluh memanfaatkan internet dalam menyusun laporan, pembuatan materi, penyusunan programa, dan mendesain metode penyuluhan maka kinerja penyuluh dalam persiapan kegiatan penyuluhan pertanian, pelaksanaan kegiatan penyuluhan pertanian, dan evaluasi penyuluhan pertanian akan semakin baik. Hal ini seperti yang dikemukakan Nort Carolina Cooperative Extension (2006) bahwa kinerja penyuluh pertanian lebih mengarah pada kemampuan penyuluh dalam mendesain program-program penyuluhan. Adanya tuntutan akan kemampuan tersebut maka seorang penyuluh membutuhkan banyak informasi yang terkait. Suryantini (2001) berpendapat bahwa kebutuhan informasi penyuluh pertanian adalah pengetahuan atau data dan fakta yang disadari sebagai sesuatu yang perlu diperoleh dan digunakan oleh penyuluh pertanian dalam mendukung tugas dan fungsinya sebagai pemangku jabatan fungsional. Berdasarkan kebutuhan tersebut Ahuja (2011) mengemukakan bahwa ketersediaan informasi melalui internet membantu proses penyuluhan pertanian lebih cepat dan efektif.

\section{Kesimpulan}

Tingkat pemanfaatan internet oleh penyuluh pertanian tergolong sedang, baik dalam menyusun laporan, pembuatan materi penyuluhan, penyusunan program penyuluhan, dan pembuatan desain metode penyuluhan. Artinya penyuluh kadang-kadang memanfaatkan internet dalam melaksanakan kegiatan tersebut. Faktor-faktor yang berpengaruh terhadap pemanfaatan internet adalah umur, pendidikan formal, persepsi terhadap internet, durasi, dan keragaman gawai/gadget yang diakses. Pemanfaatan internet berpengaruh positif terhadap kinerja. Artinya tingkat pemanfaatan internet tersebut dipengaruhi umur yang muda, pendidikan formal yang tinggi, persepsi terhadap internet yang tinggi, durasi yang lebih lama, banyaknya gawai/gadget yang diakses. Pemanfaatan internet oleh penyuluh terbukti meningkatkan kinerja penyuluh.

\section{Daftar Pustaka}

Ahuja V. 2011. Cyber Extension: A Convergence of Ict and Agricultural Development. Global Media Journal-Indian Edition. 2 (2): 1-8.

Anggoroseto P. 2012. Faktor-faktor yang mempengaruhi kinerja penyuluh dalam pemanfaatan cyber extension di Kabupaten Bogor. [Tesis]. Surakarta (ID): UNS.

Bahua MI, Jahi A, Asngari PS, Saleh A, Purnaba 
IGP. 2013. Factors affecting the performance agricultural extension and their impact at behavior maize farmers in Gorontalo Province. Journal of Agricultural Education and Extension. 1: 1-10.

Elian N. 2015. Penggunaan internet dan pemanfaatan informasi pertanian oleh penyuluh pertanian di Wilayah Barat Kabupaten Bogor. [tesis]. Bogor (ID): Institut Pertanian Bogor.

Fraenkel J, Wallen N. 1993. How to Design and evaluate research in education. 2nd ed. New York (US): McGraw-Hill Inc.

Gatut BN. 2008. Kompetensi penyuluh sarjana dalam pembangunan pertanian: Kasus di Provinsi Jawa Barat. [Disertasi]. Bogor (ID): Institut Pertanian Bogor.

Gilley WJ, Eggland SA. 1989. Principles of Human Resources Development. Toronto. Canada: Addison Wesley Publishing Company, Inc.

Hidayat SI. 2009. Analisis kinerja penyuluh pertanian di wilayah kerja unit penyuluhan pertanian Sukodono, Sidoarjo. [Jurnal]. Surabaya (ID): Habitat. 20(1): 45-56.

Kusmiati, Maryani, Kusnadi. 2010. Kinerja penyuluh pertanian PNS dalam melaksanakan tupoksi di Kabupaten Bogor (Kasus di BP3K Cibungbulang). Jurnal Penyuluhan Pertanian. 5(1): 87-103.

Lastinawati E. 2011. Partisipasi petani dalam pelaksanaan program pengembangan usaha agribisnis perdesaan (PUAP) di Kabupaten Oku. Jurnal Agronobis. 3(5):47-57.

Lestari U. 2010. Makalah: Dampak teknologi informasi dan komunikasi (TIK) terhadap aktivitas pendidikan. Jakarta (ID): Universitas Muhammadiyah Jakarta.

Leeuwis C. 2004. Communication for Rural Innovation (Rethingking Agricultural Extension). Victoria (AUS): Blackwell Publishing.

Mardikanto T. 1993. Penyuluhan Pembangunan Pertanian. Surakarta (ID): UNS Press.

Mardikanto T. 2003. Penyuluhan Pembangunan Pertanian. Surakarta (ID): UNS Press.

Mardikanto T. 2009. Sistem Penyuluhan Pertanian. Surakarta (ID): UNS Press.

Muliady TR. 2009. Faktor-faktor yang mempengaruhi kinerja penyuluh pertanian dan dampaknya pada perilaku petani padi di Jawa Barat. [disertasi]. Bogor (ID) : Institut Pertanian Bogor.

Marliati, Sumardjo, Asngari PS, Tjitropranoto P, Saefuddin A. 2008. Faktor-Faktor Penentu peningkatan kinerja penyuluh pertanian dalam memberdayakan petani (Kasus di Kabupaten Kampar Provinsi Riau). Jurnal Penyuluhan. 4(2): 92-99.

Mulyandari RSH. 2011. Cyber extension sebagai media komunikasi dalam pemberdayaan petani sayuran di Jatim dan Jabar. [disertasi]. Bogor (ID): Institut Pertanian Bogor.

Mundorf N, Laird KR. 2008. Social and psychological effects of imformation Technologies and other interactive in Jennings Bryant and Dolf Zillman Ied). Media Effects. Advances in theory and research. Lawrence Erlbaum Associates, Publisher, Mahwah, New Jersey, London.

Ningrum W, Sunuharyo BW, Hakam MS. 2013. Pengaruh pendidikan dan pelatihan terhadap kinerja karyawan.

North Carolina Cooperative Extension. 2006. Extension Agent Competencies [internet]. [diunduh 2016 Desember 23]. Tersedia pada: http: //www. ces. ncsu. edu/ pods/ agents/ knowledge. com.

Pittman RH. 2009. An Introduction to Community Development. London \& New York: Routledge.

Robbin SP. 1998. Perilaku Organisasi. Jakarta (ID): Prentice Hall.

Setiawan I. 2007. Strategi peningkatan Indeks Pembangunan Manusia (IPM) petani dengan pemanfaatan teknologi internet. Bandung (ID): Universitas Padjadjaran.

Silalahi U. 2012. Metode Penelitian Sosial. Bandung (ID): Reflika Aditama.

Suryantini H. 2004. Pemanfaatan informasi teknologi pertanian oleh penyuluh pertanian: Kasus Di Kabupaten Bogor, Jawa Barat. Jurnal Perpustakaan Pertanian. 13 (1): 17-23.

Suryantini H. 2001. Pemanfaatan informasi oleh penyuluh pertanian (Kasus Di Kabupaten Bogor Jawa Barat). [tesis]. Bogor (ID): Institut Pertanian Bogor.

Turere VN. 2013. Pengaruh pendidikan dan pelatihan terhadap peningkatan kinerja karyawan pada Balai Pelatihan Teknis Pertanian Kalasey. Jurnal EMBA. 1 (3): 10-19.

Uno HB, Lamatenggo. 2012. Teori Kinerja dan Pengukurannya. Jakarta (ID): Bumi Aksara.

Utami, B.W., Widiyanti, E,. dan A. Wibowo. 2008. Kinerja Penyuluh Pertanian Lapang (PPL) dalam pengembangan beras organic menuju terwujudnya Kabupaten Sragen sebagai sentra beras organic. Jurnal Agritexts. 24: 1-12.

Veronice. 2013. Pemanfaatan Teknologi Informasi 
Jurnal Penyuluhan, Maret 2018 Vol. 14 No. 1

dan Komunikasi dalam Peningkatan Kompetensi Penyuluh. [tesis]. Bogor (ID): Institut Pertanian Bogor.

Wuriani, Zakso A, Suib M. 2014. Kontribusi karakteristik individu dan komitmen profesional terhadap kepuasan kerja dosen prodi keperawatan.

[Jurnal].Pontianak(ID). Universitas Tanjungpura. 